\title{
FIELDWORK IN A CONTEXT OF DECOLONIZATION: THE EXAMPLE OF A FRENCH OVERSEAS TERRITORY (NEW CALEDONIA)
}

\author{
MatThias KowASCH \\ With 4 figures and 2 photos \\ Received 14 August $2013 \cdot$ Accepted 08 October 2014
}

\begin{abstract}
Summary: New Caledonia, a French overseas territory in the South Pacific that possesses more than $25 \%$ of the world's nickel reserves, is currently undergoing a process of decolonization, after a period of Civil War in the 1980s. Balanced between demands for independence of the indigenous Kanak population and political affiliation to France, there is a spatial as well as a socio-economic and cultural division of the population. I argue for socially responsible research strategies in a cross-cultural and politically charged context, and outline some of the factors that influenced my own ethnographic work. The researcher's family background and education affect the structure of relationships and behaviours. Self-presentation and institutional affiliation play an important role in daily fieldwork. Information and data collection as well as publication of research results have to respect intellectual property rights, which are tangible and intangible. An outsider position in a foreign culture can lead to discomfort, which can be tackled by working closely with local researchers and institutions. Research can be useful in this situation, if the results are made available to local people, political actors, and business.
\end{abstract}

Zusammenfassung: Neukaledonien, ein französisches Überseegebiet im Südpazifik, das über 25\% der weltweiten Nickelreserven besitzt, durchläuft nach dem Bürgerkrieg in den 1980er Jahren aktuell einen Entkolonialisierungsprozess. Hinund hergerissen zwischen Unabhängigkeitsforderungen der indigenen Kanaks und politischer Zugehörigkeit zu Frankreich zeigt sich die zweigespaltene Gesellschaft auch in der räumlichen Segregation der Bevölkerung. Dieser postkoloniale Kontext stellt den Forscher/die Forscherin vor besondere Herausforderungen. Neben dem sozio-wirtschaftlichen und politischen Kontext analysiert der vorliegende Artikel unterschiedliche Faktoren, die den Forscher/die Forscherin in seiner ethnographischen Feldforschung beeinflussen. Familiärer Hintergrund und Erziehung der Forscherin/des Forschers haben Auswirkungen auf den Beziehungsaufbau und das Verhalten zu anderen. Die eigene Präsentation und die institutionelle Zugehörigkeit spielen bei der täglichen Arbeit im Feld eine bedeutende Rolle. Bei der Informationsbeschaffung und der Publikation von Forschungsergebnissen ist das Recht auf geistiges Eigentum zu berücksichtigen, welches sowohl materielle wie auch immaterielle Dinge umfasst. Die Outsider-Situation des Forschers in einer fremden Kultur kann zu Unbehagen führen, welches durch Zusammenarbeit mit lokalen Forschern oder mit lokalen Institutionen durchbrochen werden kann. Forschung kann in diesem Sinne nützlich sein, wenn die Ergebnisse Politik, Wirtschaft und lokaler Bevölkerung zugänglich sind.

Keywords: Fieldwork, insider-outsider, relational positionality, social engagement, intellectual property, New Caledonia, decolonization, mining industry, ethnography

\section{Introduction}

In her paper "Playing the Field: Questions of Fieldwork in Geography", KaTZ (1994, 67) asks: "Where are the boundaries between 'the research' and everyday life; between 'the fieldwork' und doing fieldwork; between 'the field' and not; between 'the scholar' and subject?"

Between 2006 and 2010, I was a PhD student working on mining development, perception and participation of indigenous Kanak people in New Caledonia. I have continued with lecturing and postdoctoral research in this French overseas territory, which is situated $1,500 \mathrm{~km}$ to the East of Australia and South-West of Vanuatu. In this paper, I will question my position as a researcher conducting fieldwork in the context of decolonization. I will adopt an autoethnographic voice to situate the familial and educational background that influenced my way of thinking and my fieldwork (BuTz 2001; Butz and Besio 2009; Crossa 2012).

The anthropologist of Melanesia, MALINOwSKI, was widely praised for the richness of his work. And yet he wrote candidly in his "A Diary in the Strict Sense of the Term" (1967) that he sometimes wished to be somewhere else when he was conducting field- 
work in Papua New Guinea. This led Geertz (1983, 56) to say that "The myth of the chameleon fieldworker, perfectly tuned to his exotic surroundings, a walking miracle of empathy, tact, patience and cosmopolitanism, was demolished by the man who had perhaps done most to create it". So with some cautiousness I will analyse my own experience with immersion into local Melanesian communities. To describe and analyse strategies of participation, land conflicts in mining affected areas and negotiations about the distribution of mining benefits, I stayed several months in Kanak communities close to the construction site of a major nickel smelter and mining project. Following KATZ $(1994,70)$, the object of my study was to understand people's lives, as lived in real time and space. After a description of the political and socio-economic context of New Caledonia, I will discuss my organisation of surveys and research in the second part of this paper. Not just the context of decolonization and the struggle for independence affected my fieldwork, but also several other factors that I will analyse in a third section. I ask how intellectual property, social engagement and ethics as well as relational positionality influenced my work. The institutional affiliation and how I present myself is an important matter in "the field" and in the relationship with the "research subject". Often, researchers forget that customary knowledge is also intellectual property. But social engagement breaks down the distance between researcher and subject, challenges neutrality, and allows intellectual property to be shared to some extent. Relational positionality should therefore be included in the analysis of any fieldwork in a postcolonial context. This starts with my school education, and continues with political views and the language that I use in "the field". The key question answered in this paper is how these personal factors influenced my fieldwork in the particular context of New Caledonia, a French overseas territory, and its decolonization process.

\section{The "field": political and economic context in New Caledonia}

New Caledonia is officially a French overseas territory with 'shared sovereignty', but it is still part of the United Nations list of Non-Self-Governing Territories (see MokKadem 2013). France took possession of New Caledonia in 1853 and defeated insurrections by the indigenous Kanak population. After the end of the Second World War, the French colony became an overseas territory. In the 1970s, the indig- enous Kanaks resumed fighting against colonialism and started to claim political independence (BENSA 1990).

After a period of violent anti-colonial struggles in the 1980s by Kanak independence militants against France and white settlers (see the movie "Les médiateurs du Pacifique", 1997, director Charles Belmont), New Caledonia was placed back on the UN list of Non-Self-Governing Territories in December 1986, with the support of the Pacific Islands Forum and the Melanesian Spearhead Group (Graff 2012, 66). The Matignon Accords were signed in 1988 between the independence party FLNKS ("Front de Libération National Kanak et Socialiste"), the loyalist party RPCR ("Rassemblement pour la Calédonie dans la République"), and the French state. The Matignon Accords conferred greater autonomy from France. The administrative division of the territory changed: there were now three provinces, two of them effectively governed by the Kanak independence movement. A policy of territorial rebalancing was implemented, in favour of the Northern and the Loyalty Islands Province where the majority of the population is Kanak (Fig. 1). A self-determination referendum was set for ten years in the future. When that decade was almost over, the various political parties negotiated a new agreement to avoid further clashes, and a future referendum would adjudicate the pros and cons of independence. The Nouméa Accord, signed in May 1998, created legislative power, so that the New Caledonia government was allowed to legislate without permission from the French High Court. The French government agreed to a gradual transfer of competences to New Caledonia except sovereign powers (defence, foreign policy, police, courts and currency) (KOWASCH 2010a; 2010b; 2009). And the new Congress, to be elected in 2014, can decide whether to proceed to a referendum on the transfer of the remaining sovereign powers, in other words full political independence. If the Congress does not organize the referendum by 2018, the French State will have to execute the plebiscite. Even opponents of independence have welcomed the transfer of authority from Paris to Nouméa, but they are fiercely opposed to a final breach with the French Republic (Maclellan 2013, 17). In contrast, most indigenous Kanaks see the Nouméa Accord as a roadmap to political sovereignty. It promotes Kanak culture, establishes New Caledonian citizenship for the first time, and declares the vision of a "common destiny". For MokKadem (2013, 13), New Caledonian citizenship will still have a tough path to acceptance by the different communities in the country. "Colonial herit- 


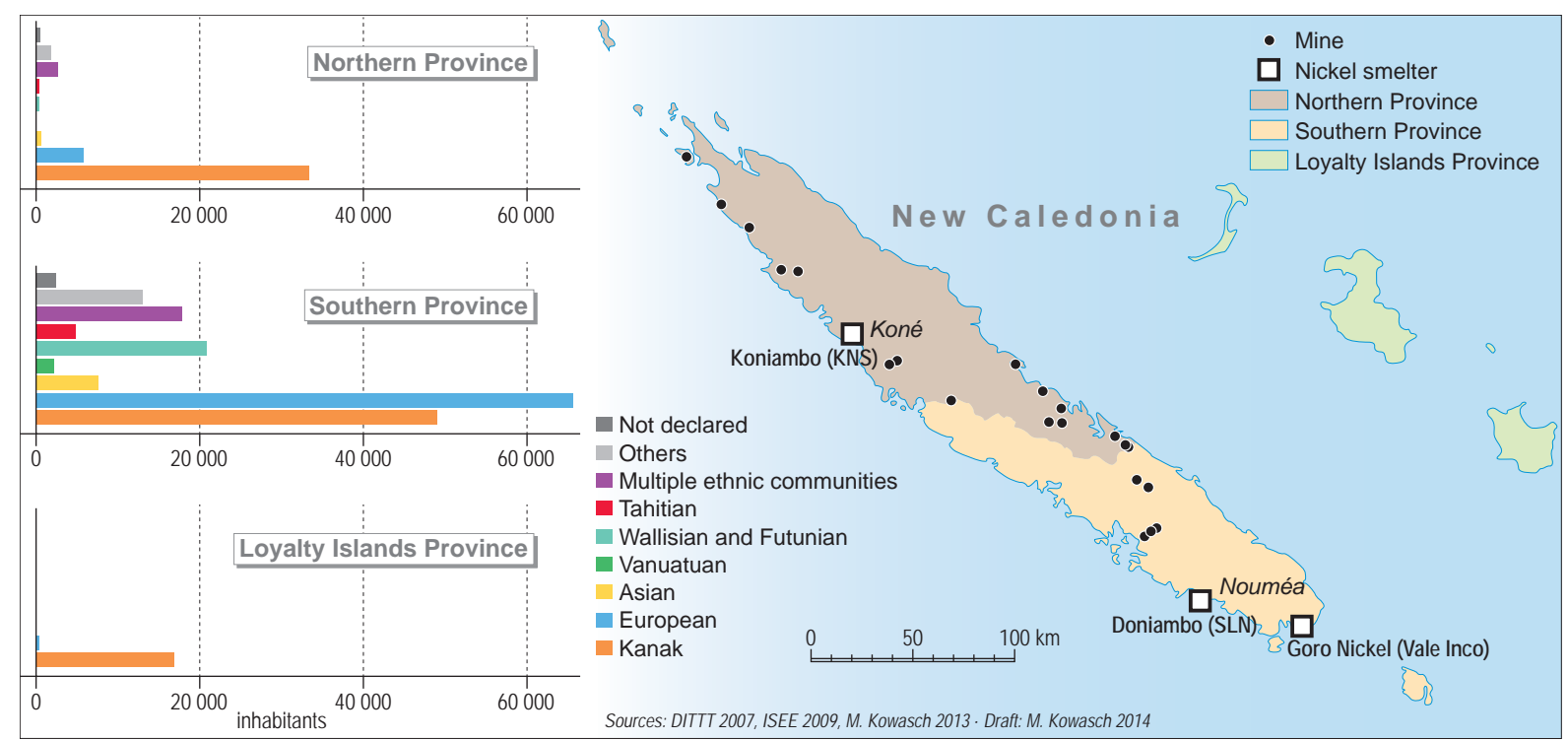

Fig. 1: Nickel industry and ethnic population distribution in New Caledonia

age persists through structural inequality between Kanaks, Caledonian communities and French people recently arrived in New Caledonia."

Today, New Caledonia is characterized by rich cultural diversity, but this diversity is more readily visible in the urban context and less so in the rural communities and at a distance from Nouméa. The indigenous Kanak represent the most important ethnic group with $40.3 \%$ of the total population in 2009 , followed by the Europeans $(29.2 \%)$ and the Wallisians/ Futunans $(8.7 \%)$. Only $8.3 \%$ of the population identified themselves as belonging to several other ethnic groups. Some $15 \%$ of the total population were born in France, most of them living in Nouméa and the neighbouring districts (http://www.isee.nc). There is a spatial segregation of Kanak and other ethnic groups. While the capital Nouméa can be described as a European city in terms of its built environment and lifestyle, Kanak people in the villages practice a way of life balanced between custom, a subsistence economy and new monetary incomes resulting from the development of the nickel industry. This has led to social upheavals.

The nickel industry plays an important role in the independence issue, because mining products represent over $90 \%$ of Caledonia's export value. The country possesses more than $25 \%$ of the world's nickel reserves. The nickel industry is currently being transformed as new joint ventures and exports to Asia challenge France's control of the strategic minerals sector (Maclellan 2013, 21). Two new nickel processing plants are being built, one in the Southern Province by the Canadian-Brazilian corporation Vale Inco
(Goro Nickel), the other in the Northern Province (Koniambo) by a local-Swiss joint venture, with the SMSP ("Société Minière du Sud Pacifique", 51\% share) and Xstrata (49\% share). The new projects break SLN's dominant position. Historically, SLN ("Société Le Nickel"), a subsidiary of the French corporation Eramet, which in turn is controlled by the French government through its FSI strategic investment fund, ran New Caledonia's only nickel processing plant called Doniambo located in Nouméa. Doniambo was built in 1910 and produces around 60,000 t of nickel metal annually. Figure 1 shows the three processing plants (Doniambo, Goro Nickel and Konbiambo) as well as the population distribution by ethnicity.

While the Kanaks are in the majority in the Northern (74\%) and Loyalty Islands Province (97\%), the Europeans represent the most important ethnic group in the South (36\%). New Caledonia has dramatic spatial disparities: of the total population $67 \%$ live in Nouméa and the neighbouring districts MontDore, Dumbéa and Paita. Some $82 \%$ of the active population work in the Southern Province where 75\% of the businesses are located. Socio-economic disparities are also conspicuous in the health and education sectors (KowASCH 2012c; ISEE census 2009, http:// www.isee.nc). New Caledonia possesses two different land tenure systems: land under common law and customary land where only Kanak live, except a few who rent properties. Customary land is inalienable. Some $18 \%$ of the main island "Grande Terre" is classified customary land. The Loyalty Islands are entirely customary land, because they don't have the same colonial history of land grabbing. 
For the Northern Province, which is the majority shareholder of the SMSP through its economic investment company SOFINOR, the nickel sector is a kind of "instrument" for wider economic development and political emancipation (NÉAOUTYINE 2006; Pitoiset and Wéry 2008; Kowasch 2012a; 2009, 11). The Northern Province is governed by the independence party PALIKA (Party of Kanak Liberation) and affiliated parties and have called for the local population (mostly Kanak, see Fig. 1) to participate in the project and to invest in it. The PALIKA see the control of the mining sector as a key part of their struggle. Mining benefits that decrease the financial dependence on France, are reinvested in other economic sectors - tourism and aquaculture for example. The Koniambo project is located in a rural area, and the public authorities want to turn this growth pole into a real urban centre, a Pacific city able to rival the capital Nouméa.

My research questions for doctoral and postdoctoral studies concern the participation of neighbouring Kanak peoples in the new mining projects, societal transformations within their communities, the relationship between customary representatives and the mining operators, conflicts around the new mining projects (about benefits, land legitimacy, etc.) and environmental practices (KOWASCH 2010a; 2012a; 2012b). The local Kanak communities perceive the Koniambo project to be "their project" capable of generating employment, new revenues and services, political emancipation, and "development". In order to better understand the multiple perceptions and the complex socio-cultural transformation processes in northern New Caledonia, I completed an empirical study in four villages in proximity to the Koniambo project.

\section{Administrative framework, choice of "the field" and organisation of surveys}

"What is the field?" - In the case of my research, I question if work in the Kanak villages, the empirical study, was the only "fieldwork" I did, or whether to include time spent in Nouméa, mainly at IRD (Institute of Research for Development). In Nouméa, I conducted interviews with officials of the mining companies, with politicians, and with customary representatives. So, do I consider the whole stay in New Caledonia as fieldwork? As a $\mathrm{PhD}$ student in a French/German university, was I - following KATZ $(1994,72)$ "always, everywhere, in the field"? Is there a difference with researcher em- ployed by the IRD research centre in Nouméa or the University of New Caledonia? Am I not in the field by living in Nouméa?

Doing a PhD at the universities of Heidelberg and Montpellier, I had the opportunity to integrate with a research unit at the local IRD centre in Nouméa: the research group ESPACE-DEV provided an office and a grant for PhD fieldwork as part of a larger research project. Later, when I came back for postdoctoral studies, my work was linked to another research unit, called GRED (Governance, Risk, Environment, Development). Delamont $(1992,70)$ describes the capture of fortunate opportunities such as this as "opportunity sampling" or, more descriptively, "snowballing", that involves seizing the chance offered by a setting, or a respondent, when the opportunity presents itself (see also BATTERBURY 1997, 78).

Another issue is the choice of "the field". KATZ (1994, 67) explains: "We - ethnographers - define a site of inquiry that is necessarily artificial in its separations from geographical space and the flow of time. In most cases, it is the ethnographer who draws the lines, defining in and out." I chose my field in the Northern Province because the neighbouring Kanak villages were undergoing dramatic socio-economic change. The four villages studied, Oundjo, Gatope, Baco and Netchaot (see Fig. 2), were selected in consultation with colleagues from IRD. Oundjo and Gatope are the closest villages to the construction site of the new smelter, on the peninsula of Vavouto. Baco is a village with large customary estates where the public authorities of the Northern Province want to build accommodation, and cultural and economic facilities. The fourth village Netchaot is located further away from the building site (over $30 \mathrm{~km}$ ) in the mountain range between East and West coast of New Caledonia. Netchaot was chosen in order to compare societal transformations in communities close to the smelter with those further away (see Photo 1).

By doing fieldwork in different locations in New Caledonia, interviewing different clans and with various methods (semi-structured surveys, informal interviews and social mapping), I moved away from the single sites and local situations of conventional ethnographic research. Marcus (1995) distinguishes different conceptual visions and possibilities that emerge from multi-sited spaces: the ethnographer can follow and stay with the movements of a particular group of people, or follow a story, a metaphor, a biography or a conflict. In New Caledonia, I followed stories of people by mapping sacred places and the connection of different clans to these places. I also 


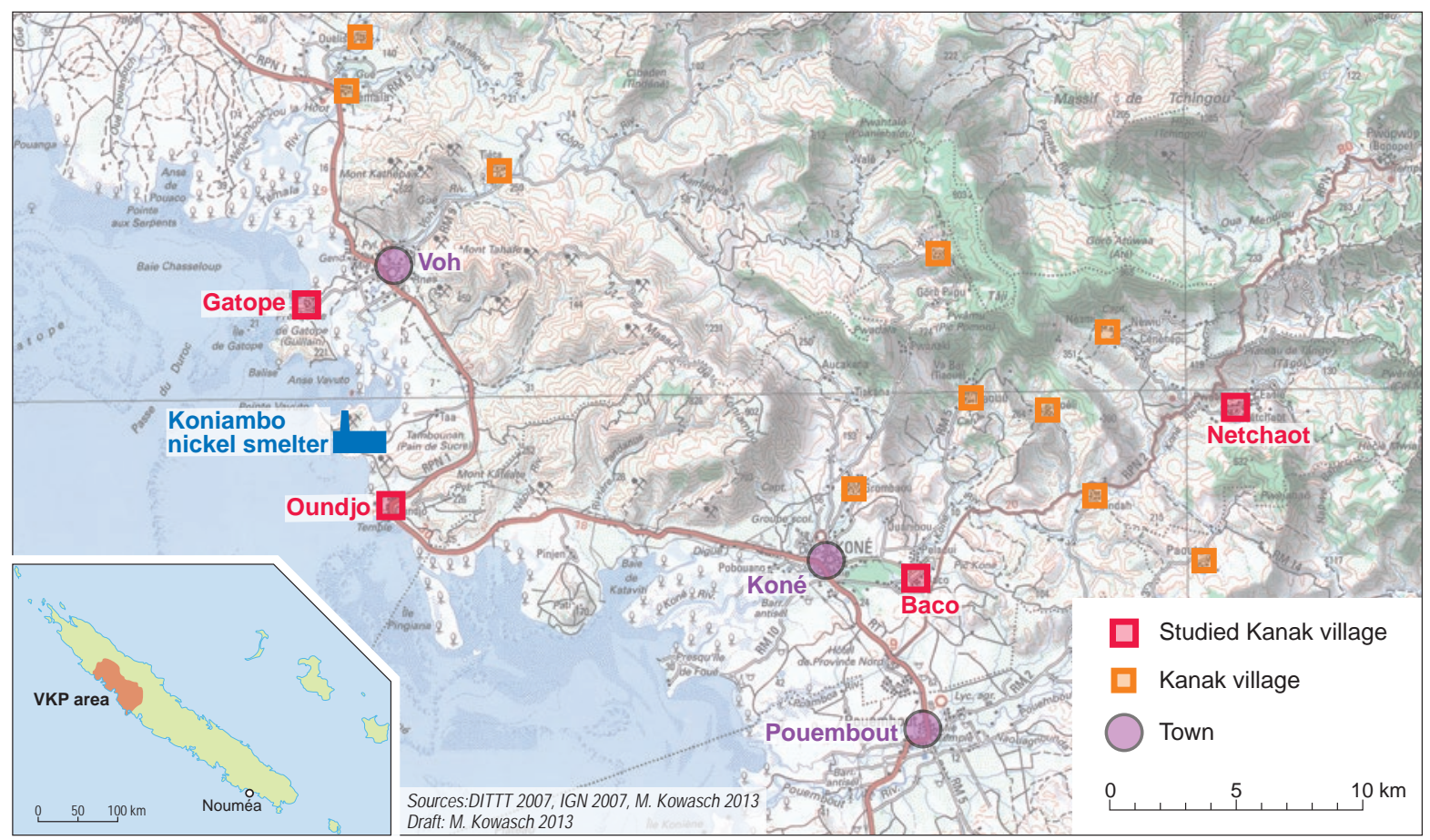

Fig. 2: Geographical location of the four studied Kanak villages

followed conflicts, because land legitimacy based on sacred places is always (re)negotiated. Moreover, the construction of a nickel smelter leads to conflicts over the distribution of benefits.

Together with locals, I conducted 239 semistructured interviews in French. New Caledonia features a great language diversity, 28 different languages and 8 dialects, but French is the official language. The standardised survey was supplemented by many informal interviews that I conducted myself. The questionnaire contained closed (age, profession, education, desire to work in the nickel sector, etc.) and open-ended questions (fears and hopes vis-à-vis the mining project, etc.). Young Kanaks between 16 and 30 years old (without experience in doing surveys) from the villages helped conduct the survey. ${ }^{1)}$ For large quantitative surveys, researchers often employ professionals who have experience with market research and survey methods. Professional experience is valuable, but to know the respondents and to codify their statements is also important. In the context of independence claims and spatial segregation between Kanaks and Europeans, I felt it was more useful to know the "research subject" in order to get true and real information. The community par-

1) Of the 239 interviews, the local research assistants did around 100 . ticipated more in my work through the involvement of the young Kanaks. For them, the survey was a good working experience. Moreover, the employment of young Kanaks (paid by IRD) represented a mechanism to vanquish isolation in another culture and to break down barriers by working in tandem with local people (see BATTERBURY 1997, 77). It was a satisfactory way to bridge social distance, but also a way for me to "give something back". And I could exchange and discuss my research methods with Kanak people.

We questioned Kanak families about professional qualifications, about fears and hopes vis-àvis the mining project, and about the maintenance of traditional activities including hunting and river fishing. Conflicts over employment, subcontracting and distribution of mining benefits were discovered, sometimes linked to "histories" of land legitimacy. Economic development and the environment are part of a game of influence between different actors (clans, businessmen, mining companies, public authorities) that leads to spatial remodelling. One of the objectives of my thesis was to develop a spatial analysis method to map the cultural value of space allocated by local people and to integrate this into regional planning. The thematic mapping of cultural sites, sacred taboos and traditional activities (fishing and hunting) was conducted with a GPS and 


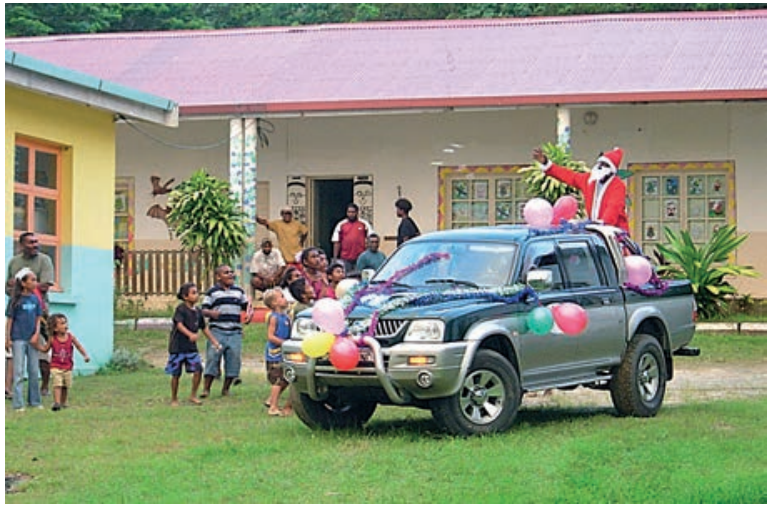

Photo 1: Christmas in Netchaot 2008 (Photo: M. Kowasch)

using ArcGIS. The results from the survey, interviews and mapping formed the basis for analysing the socio-economic transformations resulting from this vast industrial project. On the one hand, the mining project and the broader economic development of the VKP area provide employment and new revenues (see Fig. 2). On the other, involvement in the nickel sector leads to rising social disparities, to social transformation within clan organization, and disturbance of tradition and land tenure.

\section{Factors influencing "fieldwork"}

\subsection{Intellectual property}

Pursuant to the World Intellectual Property Organization (WIPO), intellectual property (IP) refers to creations of the mind: inventions, literary and artistic works, and symbols, names, images, and designs used in commerce (http://www.wipo.int/ about-ip/en/). Imitating cultural knowledge or giving the knowledge to "foreign" researchers can be seen as a kind of "dispossession of intellectual property". For example, the "Nangol" custom, an initiating ritual for young men on Vanuatu's Pentecost Island is considered to be intellectual property. Vanuatu's government claimed compensation for bungee jumping operators, because they imitated the traditional ritual. When I started fieldwork in northern New Caledonia, a clan chief warned me to feed back my research results to the local communities. According to article 27 of the Universal Declaration of Human Rights "everyone has the right to the protection of the moral and material interests resulting from any scientific, literary or artistic production of which he is the author" (UN 1948). GAGNÉ $(2011,264)$ explains the appeal of the United Nations: "Indigenous peoples appeal to in- ternational bodies, especially the UN, to voice their grievances and demands. The aim is to put pressure on states by using international opinion."

STRATHERN (2009) goes further and adds the notion of "land" to intellectual property. She describes the definition of land in two symmetrical aspects: land as a resource, potentially exploitable and appropriated ("the land belongs to us"), and land as a source of life, the principle of fertility ("we belong to the earth"). Strathern $(2009,17)$ "think of the land as a creative and its products as creations". The term "creativity" joins intellectual property rights and permits a definition of land as a material and immaterial resource (Le Meur 2010, 94). STRAthern notices $(2009,19)$ that "in Western jurisprudence land is often held up in contrast to intellectual property as the example of something that is manifestly tangible" (see also KowASCH et al. (accepted)). But in Melanesia, people value "the intangible but vital capacity for relationships that the land and its fruits mobilize" (STRATHERn 2009, 29). Bainton et al. $(2012,44)$ emphasise the social relationship of Melanesian people to land in an article about sacred places on Lihir island in Papua New Guinea: "As we have seen, changes to the landscape have been reflected in the adaptation of ritual practice; rituals have been reworked and reframed to make sense of new challenges and dislocations. New ontological relationships to the landscape are likely to give rise to new ideas about death, or even a reformulation of the existential order."

In New Caledonia, the customary associations CAUGERN (Indigenous committee of management of natural resources) and Rheebu Nuu, refer to the "Solemn Declaration of 23 August 2002 of Kanak indigenous people, claiming the right to space and natural heritage of Kanaky (New Caledonia)". Section 4 of this declaration affirms the authority of custom in the management of natural resources: "On behalf of the historic heritage, soil, sub-soil, marine and terrestrial natural areas constitute the heritage of Kanak people. Administrative and political authorities can't decide on the transformation of this heritage without the enlightened, prior and written consent of the relevant indigenous population, which will be given in the required forms. For any unacceptable project, customary authorities will exercise their right of veto." (see Demmer 2007; Kowasch 2010a, 393). Rheebu Nuu used the Declaration of 2002 and the United Nations Declaration on the Rights of Indigenous People of 2007 in order to claim land rights (as material and immaterial property) and compensation payments vis-à-vis the min- 
ing company Vale Inco that built a nickel smelter and wanted to mine in the districts of Yate and MontDore. Rheebu Nuu and the mining operator signed a "Pact for Sustainable Development of the Big South" in March 2008 that managed the question of royalties. Rheebu Nuu stopped legal measures against Vale Inco and accepted that low level discharge of dilute acid would occur in the Southern lagoon.

The Rheebu Nuu example shows that intellectual property concerns not only cultural knowledge as myths or artefacts, but also land rights. Researchers working on land issues have to be aware of intellectual property considerations.

\subsection{Insider - outsider}

While conducting empirical surveys, I lived for 17 months ( $\mathrm{PhD}$ and postdoctoral studies) in the Kanak village of $\mathrm{Baco}$, close of the provincial capital Koné. Blatkie $(2012,236)$ notices that even if "authentic" experience is desireable, institutional constraints often inhibit long periods of residence by students and researchers: "It is perhaps ironic that, while the local is reified as the site of authentic, participatory practice and indigenous knowledge, it is also the site which demands in-depth experience and knowledge of the academics who pronounce about it, but for whom the institutional constraints upon learning in depth about it is usually denied to them." In my case, my $\mathrm{PhD}$ supervisors encouraged a long stay in the village in order to get reliable data and information.

How a researcher arrives in the village is an important concern in Kanak communities. In the village of $\mathrm{Baco}$, I was introduced by the Director of the Department for Cultural Services of the Northern Province, a Kanak man from Lifou in the Loyalty islands. The pastor of Baco was also originally from Lifou. I changed my host family in Baco once, because the pastor moved to another village. The arrival within the community is a kind of "identity card". My presence in the village was always linked to my host family who welcomed me as their "son". I gave my contribution to customary ceremonies (money and/or fabric), and I participated regularly at funerals and weddings (see Photo 2). I thought that only as an insider would I understand the socio-economic processes I was interested in exploring. I did not know of Mullings' $(1999,40)$ assertion that "the insider/outsider binary in reality is a boundary that is not only highly unstable but also one that ignore the dynamism of positionalities in time and through

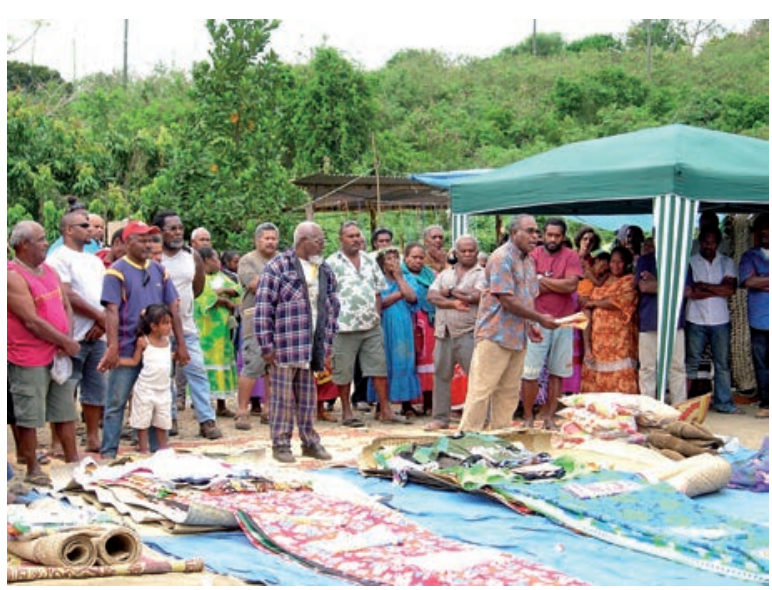

Photo 2: Wedding ceremony in Baco in August 2008 (Photo: M. KoWASCH)

space." She suggests that the researcher can to an extent integrate village and family life of the research subjects, but with uncertain positionalities over time. Positionalities are in flux, and events like marriage, death or a new occupation can change our own behaviour and relationship with others. A new political situation can also transform the insider-outsider relationship. Certainly, much information can only be acquired in staying within the community and in having "informal discussions" outside the research agenda. The boundary between the researcher and his or her subject, between the insider and the outsider is dynamic and unstable; it depends on the context and the situation. Conducting an interview at home or in a public space (restaurant, café, etc.) changes the insider-outsider relation completely. Even if the researcher wants to be a complete outsider in the field, he/she will not be outside fields of power. KATZ (1994, 68), who did her PhD fieldwork in Sudan, highlights: "I am an outsider in this context, but once there, of course, am not outside the power dynamics of the space so marked". When I interviewed a family in one of the four Kanak villages who was in conflict with another family, then I was indirectly implicated in the conflict, because the other family was informed about my presence in the village. In these small communities, everybody knows each other, and everybody knows what the others are doing during the day. So, one interview influenced the next one, because the families already had some information about my research, origins and positionality. KATz $(1994,69)$ explains that my "power/lessness (in the field and in my field) as well as that of the people with whom I work are complexly interwoven in the fieldwork process and the ways I report on my work." Sometimes, I remarked 
that customary representatives linked my presence in meetings held with public authorities to their gaining better understanding Western economic issues. At customary ceremonies, people welcomed me and expressed recognition and happiness face to face, except during some alcohol-related situations.

The complexity of power relations implicit in the research process is characterized by NAST (1994) as a state of "between-ness", which captures the unavoidable negotiation of difference when engaging with others (Crossa 2012, 115). For NAST $(1994,57)$, "difference is an essential characteristic of all social interactions that requires that we are always and everywhere in between or negotiating the worlds of me and not-me". Even if my host family in Bako received me as their son, and that was a privilege for me, I considered myself as an outsider. New Caledonia was not my home; I was not born there. And I questioned my need to keep this distance in my studies. Despite it, the boundary between the research subject and me subsided in many situations, because the relations became real friendships.

\subsection{Relational positionality and affiliation}

My family background has shaped my life: my thoughts and perceptions, how I carry myself in different contexts, how I associate with others, and how others associate with me. Crossa $(2012,111)$, who worked with street vendors in Mexico City, highlights: "They [the stories of her familial background] laid the foundations for my intellectual development and became the initial interpretative window through which I came to understand my surroundings". CROSSA is a white woman, born in Uruguay; her family moved to Mexico in 1976, when Uruguay was experiencing the first stages of what became a decade-long dictatorship. Mexico welcomed political migrants at the time. Her parents participated in protests and Communist gatherings. These personal experiences interweaved with her intellectual development (Crossa 2012, 117). She uses the term "relational positionality" to point out the complex positionalities of researchers in relation to "others" (Crossa 2012, 115). Hopkins $(2007,31)$ also explains that "positionalities may include aspects of identity race, class, gender, age, sexuality, disability - as well as personal experience of research such as research training, previous projects worked on and the philosophical persuasion of the researcher". I was born in Hanover in the North of Germany. I went to a private high school where I learnt English, French and
Latin as foreign languages. My father is originally from Silesia which Germany lost to Poland after the Second World War. So, my father became a foreigner in his own country. He moved with his mother to West Germany at the age of 18, leaving behind his possessions and his land. My parents and teachers at school taught me social justice, liberty of expression and critical questioning. My education, my relationship with my parents and my familial background was influential in shaping my research activities and in doing my fieldwork. In the New Caledonian context, I interrogated my position as a white, relatively affluent, young German man with an environmentally and socially aware background in order to achieve what ENGLAND $(1994,87)$ describes as the "need to locate ourselves in our work and to reflect on how our location influences the questions we ask, how we conduct our research, and how we write our research".

But positionalities are various, and can change in the field. Hopkins $(2007,388)$ underlines that "positionalities and identities are revealed, negotiated and managed in research encounters [...]". Shifting personal positions depend on the relation to the research subject, as MARCus (1995, 113-114) explains: "In certain sites, one seems to be working with, and in others one seems to be working against, changing sets of subjects. This condition of shifting personal positions in relation to one's subjects and other active discourses in a field that overlap with one's own generates a definite sense of doing more than just ethnography [...]." HaraWAY (1991) underlines that multi-sited ethnographic research is always conducted with a keen awareness of being within the landscape, and as the landscape changes across sites, the identity of the ethnographer requires renegotiation. In this way, the researcher is also influenced by the fieldwork context and by the research subject. Referring to the outsider-position and to MaLinowski's (1967) "discomfort with other landscapes and cultures", I tried to find similarities with own experiences and personal history in a cross-cultural situation characterized by social distance between myself and other. HarveY (1996, 360) clarifies: "Difference can never be characterised, therefore, as 'absolute otherness', a complete absence of relationship or shared attributes. [...] To discover the basis of similarity (rather than the presume sameness) is to uncover the basis for alliance formation between seemingly disparate groups)." Thus, the researcher is called to reflect critically his/her multiple positionalities and the way in which various identities may influence and shape research processes and outcomes. 
Such reflexivity, however, focuses mainly "[...] on examining the identities of individual researchers rather than on how such identities intersect with institutional, geopolitical and material aspects of their positionality" (NAGAR and GEIGER 2007, 268). So, how did I present myself during fieldwork? The construction of self affects the relationship with others and channels the studies that follow. Generally, the "presentation of self" (GOFFMAn 1959) is linked to other organisations and institutions known to the locals. BeBBington (1990) argues there is a "hermeneutic advantage" to affiliation with a known and trusted international, or national, research centre. Following BATTERBURY (1997, 65), “one's own affiliation (as a project staff member, consultant or student, for example) is extremely important". BATTERBURY was a British $\mathrm{PhD}$ student with a research contract with GTZ (German technical assistance organisation). After doing fieldwork in Mossi communities in Burkina Faso, he argued that "it is important to bear in mind what sort of impact the affiliation may have on local perceptions of you the researcher, and whether there will be freedom to pursue an individual line of research which permits critique and reflection. It is unfortunate if the organisation is unpopular in the host region, perhaps because of the way its previous interventions have been conducted." (BAtTerbury 1997, 71). Goffmann $(1959,1)$ explains that locals will utilise what they already know about an organisation as a 'sign vehicle' guiding their assessment of the person. Arriving in the Kanak villages, I presented myself as a German PhD student affiliated to a German and a French university. The indigenous Kanak communities all have experience with French researchers, because there have been many French anthropologists and social scientists. And not all research and development projects are welcomed. Also, there are only a very small number of Kanak researchers in universities and research institutes and almost no social scientists. So what kind of links allowed Kanak communities to "become acquainted" with the researcher? Who is the strange new arrival? What organisation is he/she with? And who pays her/him? An important point for the assessment of local Kanak communities is the funding of the researcher: It made a difference if the project was funded by a mining company, by a French research centre or by a "foreign" university.

This question of how the researcher's affiliation and funding influence the conduct of ethnographic fieldwork is scarcely discussed. Having a German nationality, not French was - in the context of French colonial history and the current process of decolo- nization - rather an advantage when dealing with Kanak respondents. But the French IRD research centre in Nouméa was for a long period seen as a colonial institution, recruiting only French researchers. After the Civil War in the 1980s, pro-independence IRD researchers were sent back home to France. For many years after that, there were no social sciences at IRD. This situation is slowly changing (there are now two anthropologists), but I preferred a more independent and neutral standing by explaining to the Kanak communities that I had German-French funding for my PhD. Later, as a postdoctoral researcher at IRD, I introduced myself as a German researcher employed by IRD.

The intersection between various positionalities and institutional affiliation represents one critique of the discussion around "reflexivity" and "reflective identification" of the fieldworker. Rose (1997, 312) thinks that the search of positionality through transparent reflexivity will inevitably fail, because "the identity to be situated does not exist in isolation but only through mutually constitutive social relations". She sees a contradiction when a "researcher situates both herself [himself] and her [his] research subjects in the same landscape of power". NAGAR and Geiger $(2007,271)$ add three other problems. First, the discussion of the researcher's identity and positionality does not apply to scholars using quantitative research methods. Secondly, to squeeze the multifaceted and changing relationships with the research subjects into a few pages entails a translation that necessarily does injustice to their complexities. Thirdly, self-reflexivity can generate feelings of paralysis, because it does not redistribute income and it does not gain political rights for the powerless (see also Wolf 1997, 35).

The questions remains how we can avoid relational positionality and reflexivity from struggles over legitimacy and transparent reflexivity and turn them into conceptual tools that help us to generate (self-) critical and useful knowledge? NADAR and Geiger (2007) propose a "speaking-with research subjects"-approach and a "crossing borders with situated solidarities"-approach. Fieldworkers have to talk and listen carefully, and discuss more explicitly with economic and political institutions. They should not be trapped in the "first world" or in the "third world", but develop counter discourses by sharing and working with others, and by "smuggling ideas across the lines" (EDWARD SAID, quoted in JACKA 1994, 667). In the case of ethnic and social divides in New Caledonia, open, constructive and cooperative practices have been very important for me as a white 
researcher working in indigenous Kanak communities. Social engagement with Caledonian institutions and 'situated solidarities' with local communities can contribute to develop useful outcomes.

\subsection{Engagement and ethics}

The geographer BLAIKIE (2012, 238) highlights the pros and cons of the social engagement of researchers: "On the one side there is a vertiginous fall into co-optation, post-colonial rip-off, reinforcement of centralised control and the reproduction of environmental injustice. On the other side, there are charges of irrelevance, coffee table talk, clever words, introversion, academic promotion but no action outside the Ivory Tower and a denial of social responsibility."

In the New Caledonian context of decolonization, social and political engagement can be controversial, but in many situations a positioning can't be avoided. The independence movement is largely supported by Kanak people. By conducting surveys within Kanak communities, the people interviewed surmise the researcher's opinion on independence, even if he/she wants to stay "neutral". In informal interviews customary representatives, clan members and chiefs asked what "I" thought about the mining project and what "my position" is on the political independence issue. Because I was hosted by a Kanak family, I was often associated with pro-independence views. They may have linked me to several anthropologists who worked within Kanak communities and who supported the independence movement (for example AlbBAN BENSA). Complete neutrality is impossible, and the researcher has to assume a social responsibility when in the field. Following Burawoy (2004), Batterbury (2013, 2) explains: "It is perfectly possible to pursue classical scholarly work ('professional' in Burawoy's terms) while doing much more - working with constituencies outside the university completely, designing initiatives together, and committing to practical rather than only to in-theory concepts of justice." BATTERBURY (2013, 2) observes that such engagement can lead to trouble with scientific colleagues and within research institutes: "But if engaged and public work does not result in referred outputs and lucrative grants, it again troubles the neoliberal university model." Among scientific colleagues in New Caledonia (University of New Caledonia and IRD), I found that an ethnographic study, a long-stay in Kanak villages and social engagement within the communities can breed interest and encouragement, but also suspicion and difficulties with colleagues, because there is still a socio-cultural gap between Kanaks and French overseas peoples.

The ADCK (Agence de Développement de la Culture Kanak) founded in 1988 has the goal of enhancing Kanak linguistic and archaeological heritage in order to preserve them for future generations. To collect myths, songs and other forms of cultural heritage (craft arts, visual arts, etc.), the ADCK employs "cultural collectors" in the villages, generally customary representatives. Unfortunately, the material collected is often not published and the transmission to younger people is not guaranteed. During my PhD and postdoctoral studies, I collaborated with cultural collectors in the villages of Baco, Koniambo and Netchaot (all in the Northern Province). We pointed out sacred places with a GPS or on a paper map before exporting the data in a GIS. The challenge was to develop a method of spatial analysis to map the heritage value attributed by Kanak people and to make this new information available in regional planning programs (KOWASCH 2012b, 195-196). This collaboration was not "neutral". The mapping of sacred places strikes directly at identity, because Kanak identity is written in space. It is a kind of itinerary of the places where the clan has lived in past and present (KOWASCH 2012a, 203; see also Bensa 1995, 78; Naepels 2006; WinsLOW 1995).

Figure 3 is one result of my collaboration with the cultural collector in Baco. The sacred places in the map are written in "Haeke", the Kanak language spoken in Baco. The legend of the original map in my $\mathrm{PhD}$ thesis is in French, because it was important for me that local people can read my thesis and can use the maps. An example of a sacred place in the village is "Camoadoope", the ancient chief house ("ancienne chefferie" in French). "Camoadoope" signifies "big land" in Haeke language. "Foa kovai koohnê" is the confluence of a small river that has his source at Mount Koohnê ("kovai koohnê" in Haeke).

The new data contributed to mapping the cultural value of place, but the collaboration signified a commitment to the promotion of Kanak culture. This was a choice, because both the cultural collectors and I as a researcher could profit from the work, the discussions and the exchanges. In such a case, it is important not to fall into postcolonial rip-off situation as BLAIKIE terms it, and therefore into dispossession of intellectual property. A real partnership means enough space for expression by the research- 


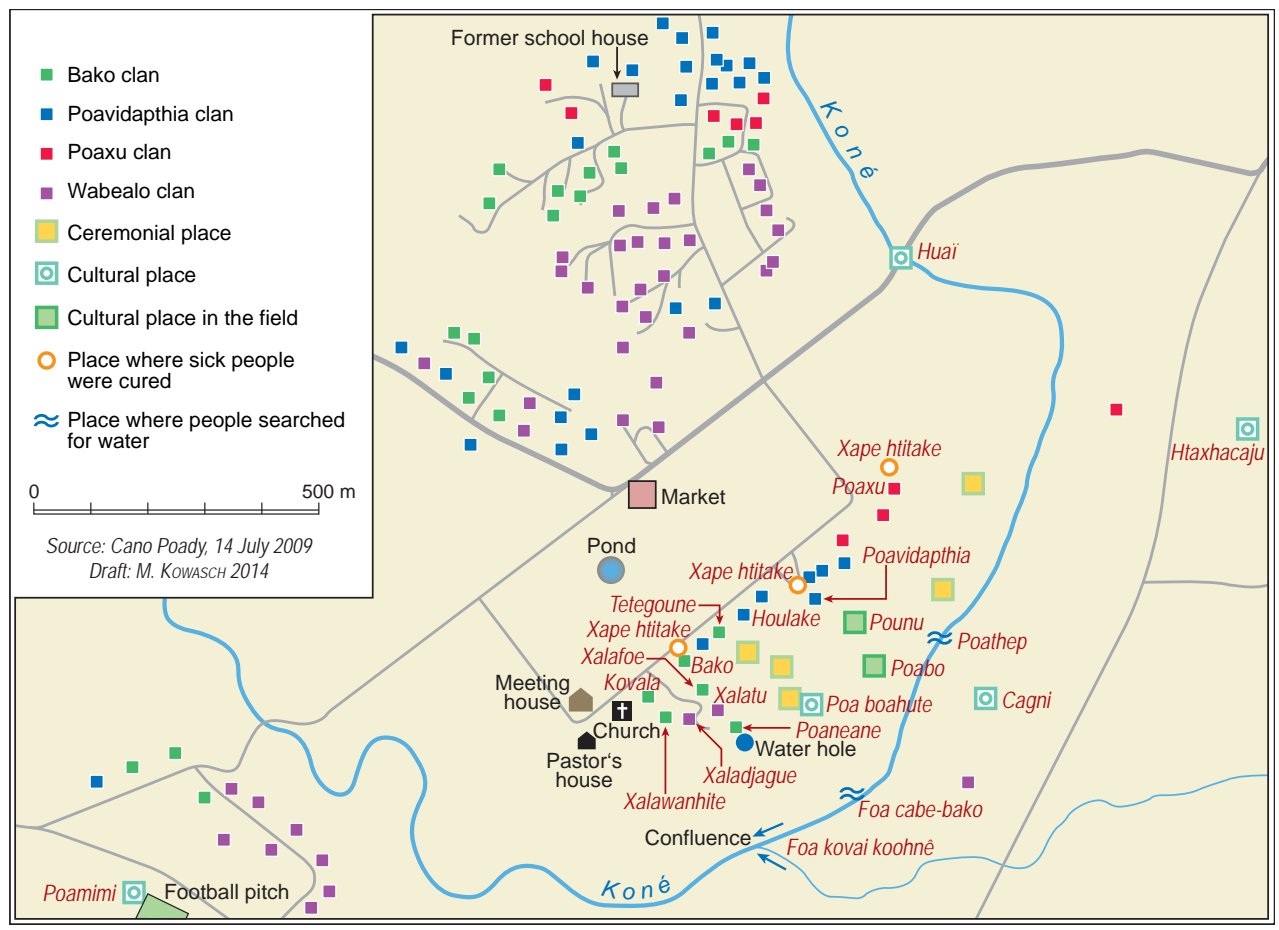

Fig. 3: Mapping of sacred places and Kanak clan settlement in the village of Baco

er and the cultural collector. Both are "learners" and "teachers" at the same time. The collaboration was an opportunity to verify preconceived notions of ethics and understandings.

We have to distinguish an engagement inside and outside the academy. A critical geography acknowledges an appeal to an external reality and is often more suited for communication with actors and institutions outside the academy. In the discipline of human geography, a number of researchers have engaged with others outside the academy in political and policy matters. ROCHELEAU (2008) and Rocheleau et al. (1996) explain the ways in which feminist political ecologists engage with various issues of justice in their work. RoBBins (1998) has dealt with "institutions of authority and environment" in Rajasthan (India). The geographer CAROLIN SCHURR has conducted $\mathrm{PhD}$ research on identity and political change in Ecuador (2008-2012); she was especially engaged in a political empowerment process for women and the emergence of parties organized around indigenous identity (SCHURR 2013). In my $\mathrm{PhD}$ and postdoctoral research in New Caledonia, I worked with customary representatives, cultural collectors as well as provincial institutions - all outside the academy. Within the regional planning program of three districts (Voh, Koné and Pouembout) in the Northern Province, I was employed as a consultant for an urban planning office for three months. Some critics suggest that such work involves financial gain, and therefore undertaking policy relevant research of this type corrupts the project on ethical grounds. Sure, some researchers get quite a lot of money from consultancy. However, engagement outside the academy can be useful and contribute to exchange between researchers and public authorities. Following BEBBINGTON $(1993,174)$, researchers can act as "conduits" or "brokers", transmitting ideas and resources in both directions, to the institutions and to the locals.

\section{Conclusion}

Fieldwork in New Caledonia is subject to particular conditions. The French overseas territory is undergoing a process of decolonization, after a period of racial struggle and civil war in the 1980s. Spatial segregation between Kanak and European populations, and the difficult quest for a common destiny influenced my relationship with Kanak communities that I lived in and studied. New Caledonia still has dramatic disparities between poor and rich people, and overlapping ethnic distinctions that can impede research work. Economic development in recent years, based largely on the nickel sector, has 


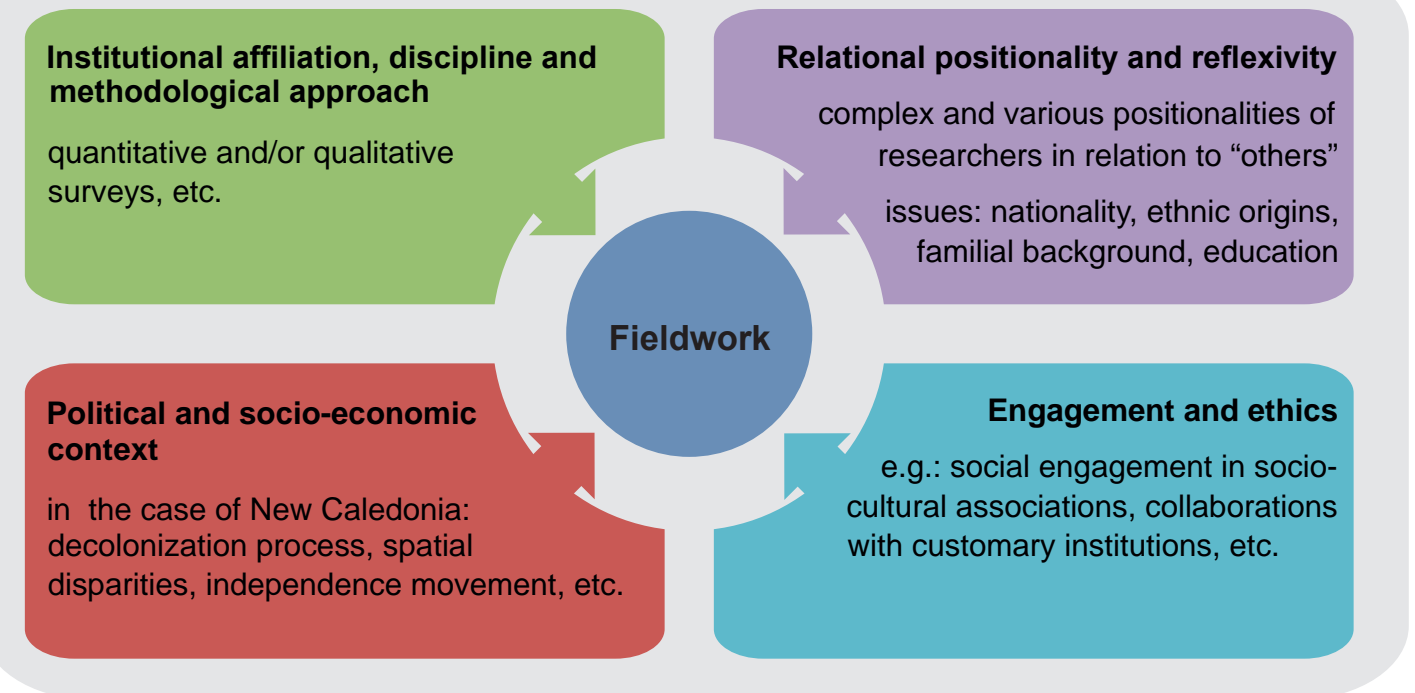

Fig. 4: Factors influencing ethnographic fieldwork

brought cash flows to Kanak villages, but has also led to social upheavals and conflicts between clans and families.

Nevertheless, it was not only the particular political and socio-economic context that affected my fieldwork. Figure 4 shows different factors that manipulate the researcher's fieldwork and the interaction between researcher and subject. The positionalities of researchers in relation to "others" are complex and various. By doing multi-sited ethnographic research, personal position changed across the sites and the people I interviewed. Family background and education shape the way of thinking and the interaction with "others". In New Caledonia, I considered myself as a "foreigner" both on fieldwork within Kanak communities and among European people in the capital Nouméa. "Foreignness" was an important quality. Nevertheless, the insider-outsider-relation is permanently changing. So my position was constituted in spaces of betweenness, what Mascia-Lees et al. $(1989,33)$ call "a position that is neither inside nor outside".

Measurable research outputs and publication in international journals need to consider intellectual property. Collecting data within indigenous Kanak communities in a context of decolonization can be seen as "dispossession of intellectual property". Everyone has the right to the protection of the moral and material interests resulting from any research work. Recording customary knowledge, mapping land claims or sacred places are examples of scientific production in which Kanak people have an interest.
Geographical research in postcolonial settings can be "useful". Selling your soul to the devil, or being corrupted by money is undesirable and unethical. Research must be "independent", but an engagement outside the academy can contribute to regional planning programs or to the socio-cultural policies of public institutions. Researchers can leave their "ivory tower" in order to collaborate with public authorities. Engagement in local institutions and work in tandem with locals is a way to "give something back". In New Caledonia, I was involved in family and village life and work that that has contributed to the deeper understanding of social transformations and perceptions of mining projects. The mapping of sacred places with cultural collectors contributed to a larger research program in the Northern Province. Referring to JEAN Drèze (quoted in The Independent 1990, November 15), "I believe that we have to be involved in the world to write about it. I use my research as one way of expressing my concern for the world, just as I use peace action ..." . Researchers take on a social responsibility by interacting with others, and when they write about other cultures and behaviours.

I admit that disciplines use different methodological approaches. These affect the interactions with local communities and modify one's own behaviour vis-à-vis others. In the field in New Caledonia, I met a lot of anthropologists doing ethnographic studies with longer or shorter stays in the villages. There were only a handful of geographers working in similar conditions. Nevertheless, human and critical geography has to play a role; and it combines quanti- 
tative and qualitative studies, statistical and spatial analysis with participatory observation. Whatever the discipline, however, the institutional affiliation as well as the relational positionality and the social engagement influence the research process, disturb power relations, and permeate everyday encounters.

\section{Acknowledgements}

I'd like to thank the research groups ESPACEDEV and GRED at the IRD centre in Nouméa for logistic help, grants and encouragement. At IRD, I participated in the research projects "GERSA" and "Mining Governance". As well, I'd like to express my deep thanks to "my" Kanak family and to the village of Baco where I spent a lot of time. The welcome was always affectionate. I am indebted to all people that answered my questions and to all who helped me to realise the surveys. The PhD was conducted between 2006 and 2010, followed by postdoctoral studies.

Concerning this paper, I am deeply grateful to Simon Batterbury for advice, assistance and comments. Thanks also to Hermann Mückler for comments and encouragement.

\section{References}

Bainton, N. A.; Ballard, C. and Gillespie, K. (2012): The end of the beginning? Mining, sacred geographies, memory and performance in Lihir. In: TAJA (The Australian Journal of Anthropology), 23, 22-49. DOI: 10.1111/j.17576547.2012.00169.x

BATTERBURY, S. (1997): Alternative affiliations and the personal politics of overseas field research: some reflections. In: Robson, E. and Willis, K. (eds.): Postgraduate fieldwork in developing areas: a rough guide. Developing Areas Research Group Monograph 9 (2 $2^{\text {nd }}$ ed.). London, 85-112. http:// www.simonbatterbury.net/pubs/

- (2013): Who are the radical academics today? Blog post. Simonbatterbury.wordpress.com

BebBington, A. J. (1990): Indigenous agriculture in the central Ecuadorian Andes; the cultural ecology and institutional conditions of its construction and its change. $\mathrm{PhD}$ thesis Worcester, MA.

- (1993): Peasant federations, development institutions, and technological change in the Andes. In: GLADE, W. and REILLY, C. A. (eds.): Inquiry at the grassroots: an Inter-American Foundation fellowship reader. Arlington, VA, 153-176.

BENSA, A. (1990): Nouvelle-Calédonie - Vers l'émancipation. Paris. - (1995): Chroniques kanak: l'ethnologie en marche. Paris.
BLAIKIE, P. (2012): Should some political ecology be useful? The Inaugural Lecture for the Cultural and Political Ecology Specialty Group, Annual Meeting of the Association of American Geographers, April 2010, In: Geoforum 43 (2), 231-239. DOI: 10.1016/j.geoforum.2011.08.010

Burawoy, M. (2004): For public sociology. In: American Sociological Review 70 (1), 4-28. DOI: 10.1177/000312240507000102

Butz, D. (2001): Autobiography, autoethnography and intersubjectivity: analysing communication in Northern Pakistan. In: Moss, P. (ed.): Placing autobiography in geography. New York, 149-166.

Butz, D. and Besio, K. (2009): Autoethnography. In: Geography Compass 3, 1660-1674. DOI: 10.1111/j.17498198.2009.00279.x

Crossa, V. (2012): Relational positionality: conceptualizing research, power, and the everyday politics of neoliberalization in Mexico City. In: ACME 11 (1), 110-132.

Delamont, S. (1992): Fieldwork in educational settings, methods, pitfalls and perspectives. London.

Demmer, C. (2007): Une nouvelle stratégie kanake. In: Vacarme 39, 43-48. http://www.vacarme.org/article1306.html

ENGLAND, K. (1994): Getting personal: reflexivity, positionality, and feminist research. In: Professional Geographer 46 (1), 80-89. DOI: 10.1111/j.0033-0124.1994.00080.x

Gagné, N. (2011): La stratégie autochtone - ses trajectoires en Océanie. In: Faberon, J.-Y.; Fayaud, V. and Regnault, J. M. (eds.): Destins des collectivités politiques d'Océanie. Vol. 1: Théories et pratiques. Aix-enProvence, 263-271.

GeERTz, C. (1983): From the native's point of view: on the nature of anthropological understanding. In: GEERTz, C. (ed.) Local knowledge. New York, 55-70.

Goffman, E. (1959): The presentation of self in everyday life. New York.

GrAFF, S. (2012): Quand combat et revendications kanak ou politique de l'Etat français manient independence, decolonisation, autodétermination et autochtonie en Nouvelle-Calédonie. In: Journal de la Société des Océanistes, 134, 61-83.

Haraway, D. J. (1991): Simians, cyborgs, and women. The reinvention of nature. New York

Harvey, D. (1996): Justice, nature and the geography of difference. Oxford.

Hopkins, P. E. (2007): Positionalities and knowledge: negotiating ethics in practice. In: ACME 6 (3), 386-394. http://www.acme-journal.org/vol6/PEH.pdf

JACKA, T. (1994): Countering voices: an approach to Asian and feminist studies in the 1990s. In: Women's Studies International Forum 17 (6), 663-672.

Katz, C. (1994): Playing the field: questions of fieldwork in geography. In: Professional Geographer 46 (1), 67-72. DOI: 10.1111/j.0033-0124.1994.00067.x 
Kowasch, M. (2009): Neukaledonien zwischen Staatenbildung und Ressourcenausbeutung. Neue Nickelprojekte als Hebel für einen politischen Emanzipierungsprozess und zum Abbau von Disparitäten? In: Pacific News 32 8-11. http://www.pacific-news.de/pn32/pn32_kowasch.pdf

- (2010a): Les populations kanak face au développement de l'industrie du nickel en Nouvelle-Calédonie. $\mathrm{PhD}$ thesis. http:/ / www.ub.uni-heidelberg.de/archiv/12305

- (2010b): Neukaledonien. In: DitTmann, A.; Gieler, W. and KoWASCH, M. (eds.): Foreign policy of Oceanic states - a handbook: from Australia to New Zealand, from Samoa to Vanuatu. Paderborn, 207-218.

- (2012a): Le développement de l'industrie du nickel et la transformation de la valeur de l'environnement en Nouvelle Calédonie. In: Journal of Political Ecology 19, 202-220. http://jpe.library.arizona.edu/volume_19/Kowasch.pdf

- (2012b): Les lieux toponymiques en Nouvelle-Calédonie un champ de recherche ouvert. In: Enquêtes Rurales 14, 187-208.

- (2012c): La zone Voh-Koné-Pouembout. In: Banvallot, J. and GAY, J.-C. (eds.): Atlas de la Nouvelle-Calédonie. Montpellier, 231-234.

Kowasch, M.; Batterbury, S. and Neumann, M. (accepted): Contested sites, land claims and economic development in Poum, New Caledonia. In: Settler Colonial Studies.

Le Meur, P.-Y. (2010): La terre en Nouvelle-Calédonie: pollution, appartenance et propriété intellectuelle. In: Multitudes 41, 91-98.

Maclellan, N. (2013): Politics heats up in New Caledonia. In: Islands Business, February 2013. http:/ /www.islandsbusiness.com/2013/2/cover-story/politics-heats-up-in-newcaledonia/

MaLINOwSKI, B. (1967): A diary in the strict sense of the term. New York.

Marcus, G. E. (1995): Ethnography in/of the world system: the emergence of multi-sited ethnography. In: Annual Review of Anthropology 24, 95-117.

Mascia-Lees, F. E.; Sharpe, P. and Cohen, C. B. (1989): The postmodernist turn in anthropology: cautions from a feminist perspective. In: Journal of Women in Culture and Society 15, 7-33.

Mokkadem, H. (2013): Kanaky ou Nouvelle-Calédonie, souveraineté et indépendance dans l'ère post-coloniale, In: Revue Asylon(s) 11. http://www.reseau-terra.eu/article1284.html

Muluings, B. (1999): Insider or outsider, both or neither: some dilemmas of interviewing in a cross-cultural setting. In: Geoforum 30 (4), 337-350. DOI: 10.1016/S00167185(99)00025-1

NAEpels, M. (2006): Réforme foncière et propriété dans la region de Houailou (Nouvelle-Calédonie). In: Etudes Rurales, Janvier-Juin, 43-54.

Nagar, R. and Geiger, S. (2007): Reflexivity and positionality in feminist fieldwork revisited. In: TiCKell, A.; SHEPPARD,
E.; Peck, J. and Barnes, T. (eds.): Politics and practice in economic geography. London, 267-278.

NAST, H. (1994): Women in the field: critical feminist methodologies and theoretical perspectives. In: Professional Geographer 46 (1), 54-66. DOI: 10.1111/j.00330124.1994.00054.x

Néaoutyine, P. (2006): L'indépendance à présent - identité kanak et destin commun. Paris.

PeEt, R. (2003): Unholy trinity: the IMF, the World Bank, and the WTO. London.

Pitoiset, A. and Wéry, C. (2008): Mystère Dang. Nouméa.

RoBBIns, P. (1998): Authority and environment: institutional landscapes in Rajasthan, India. In: Annals of the Association of American Geographers 88 (3), 410-435. DOI: 10.1111/0004-5608.00107

Rocheleau, D. (2008): Political ecology in the key of policy: from chains of explanation to webs of relation. In: Geoforum 39, 716-727. DOI: 10.1016/j.geoforum.2007.02.005

Rocheleau, D.; Thomas-Slater, B. and Wangari, E. (1996): Feminist political ecology: global issues and local experience. London.

Rose, G. (1997): Situating knowledges: positionality, reflexivities and other tactics. In: Progress in Human Geography 21 (3), 305-320. DOI: 10.1191/030913297673302122

SCHurR, C. (2013): Performing politics, making space: a visual ethnography of political change in Ecuador. Stuttgart.

STRATHERN, M. (2009): Land: intangible or tangible property? In: Chesters, T. (ed.): Land rights. The Oxford Amnesty Lectures 2005. Oxford, 13-38.

The Independent (1990, November 15): Down and Out by Preference.

UN (United Nations) (1948): The Universal Declaration of Human Rights. http://www.un.org/en/documents/ udhr/index.shtml\#a27

WINSLOW, D. (1995): Indépendance, savoir aborigène et environnement en Nouvelle-Calédonie. In: Journal of Political Ecology 2, 1-19. http://jpe.library.arizona.edu/ volume_2/WINSLOW.PDF

WoLF, D. L. (1997): Situating feminist dilemmas in fieldwork. In: Wolf, D. L. (ed.): Feminist dilemmas in fieldwork. Boulder, 1-55.

\section{Author}

Dr. Matthias Kowasch University of Bremen Department of Geography Bibliothekstr. 1 28359 Bremen Germany kowasch@uni-bremen.de 